\title{
Impementasi Metode Naive Bayes Untuk Prediksi Harga Emas
}

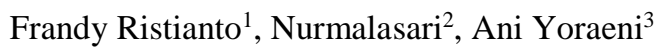 \\ ${ }^{1,2,3}$ Program Studi Sistem Informasi,Sekolah Tinggi Manajemen Informatika dan Komputer Nusa Mandiri \\ Jl. Jatiwaringin Raya No.02 Cipinang Melayu Kecamatan Makasar Jakarta Timur, Indonesia \\ email: frandy826@gmail.com,nurmalasari.nmr@nusamandiri.ac.id,ani.ayr@bsi.ac.id
}

Artikel Info : Diterima : 18-01-2021 | Direvisi : 21-01-2021 | Disetujui : 25-01-2021

\begin{abstract}
Abstrak - Emas merupakan salah satu asset yang menguntungkan untuk di investasikan. Dengan Resiko yang tidak terlalu besar. Tetapi banyak faktor yang mempengahruhi harga emas salah satunya Fluktuasi kurs (Rp) rupiah dengan mata uang USD (US Dollar). Data Mining digunakan untuk mempredisi harga emas ,dengan proses pengambian data masa lampau, data yang digunakan adalah dari data www.bps.go.id untuk menggali nilai tambah berupa informasi yang selama ini tidak di ketahui secara manual dari suatu basis data agar dapat mengetahui pola serta dapat melakukan prediksi harga emas. Salah satu metode data mining yang di gunakan yaitu Naïve bayes dan menggunakan software Rapid miner sebagai proses untuk membantu perhitungan dengan data set yang digunakan selama 3 tahun yaitu dari Januari 2016 - Desember 2019 dan data training prediksi 1 tahun kedepan dengan asumsi harga stabil, dengan pengujian sebanyak 5 kali 52 data, di mana dalam penggunaan dalam melihat peluang berdasarkan histori kejadian yang terjadi sehingga akurasinya cukup baik sebesar $95,92 \%$ dalam pengunaan serta melihat peluang profit ya atau tidaknya harga emas
\end{abstract}

Kata Kunci : Algoritma Naïve Bayes, Prediksi, Data Mining.

Abstracts - Gold is a profitable asset to invest in. With a risk that is not too big. However, many factors influence the price, one of which is the fluctuation of the exchange rate (IDR) rupiah against the USD currency (US Dollar). Data Mining is used to predict the price of gold, with the process of extracting past data, the data used is from the www.bps.go.id data to add added value in the form of information that has not been known manually from a database in order to see patterns and can predict the price of gold. One of the data mining methods used is Nä̈ve Bayes and uses Rapid Miner software as a process to assist calculations with the data set used for 3 years, namely from January 2016 - December 2019 and prediction of data training for the next 1 year assuming stable prices, with testers as much as 5 times 52 data, where in the application of opportunities based on the history of events that occurred so that the accuracy is good at $95.92 \%$ to apply and see profit opportunities whether or not the gold price

Keywords : Nä̈ve Bayes Algorithm, Prediction, Data Mining

\section{PENDAHULUAN}

Emas merupakan salah satu asset yang menguntungkan untuk di investasikan. Dengan Resiko yang tidak terlalu besar. Tetapi banyak faktor yang mempengahruhi harga emas salah satunya Fluktuasi kurs (Rp) rupiah dengan mata uang USD (US Dollar).

Fluktuasi harga emas dipengaruhi oleh banyak faktor seperti kondisi perekonomian, laju inflasi, penawaran dan permintaan serta masih banyak lagi."Di karenakan Fluktuasi harga emas yang dapat menjadi peluang bagi orang yang berinvestasi mas baik emas digital maupun emas fisik.dan agak sulit xmelihat peluang dari perubahan harga emas dengan perubahan kurs rupiah(Guntur, Mohammad;Santony, 2018)

Average-Based Fuzzy Time dengan kelebihan untuk menentukan interval secara efektif, interval yang dibentuk mengimplementasikan Average based length sehingga dapat meningkatkan ketepatan prediksi yang dihasilkan.(Riduan et al., 2020)

This work is licensed under a Creative Commons Attribution-ShareAlike 4.0 International License. 
The Naïve Bayes Classifier (NBC) adalah teknik prediksi berbasis probabilistik sederhana berdasarkan penerapan teorema bayes atau aturan dengan asumsi independensi yang kuat pada fitur, yang berarti bahwa fitur pada data tidak terkait dengan ada atau tidak adanya fitur lain dalam data yang sama(Haryanto \& Saputra, 2018)

RapidMiner adalah platform perangkat lunak data science yang dikembangkan oleh perusahaan dengan nama yang sama yang menyediakan lingkungan terpadu untuk persiapan data (data preperation), pembelajaran mesin (machine learning), pembelajaran mendalam (deep learning), penambangan teks (text mining), dan analisis prediktif (predictive analytics).(Wahono \& Riana, 2020)

Emas merupakan salah satu logam mulia yang banyak diminati masyarakat sebagai komoditi untuk berinvestasi dikarenakan ketahanannya terhadap laju inflasi yang cukup baik. Namun Seiring perkembangan zaman ada kalanya fluktuasi terjadi begitu ekstrim sehingga mempengaruhi nilai emas. Oleh karena itu mengetahui prospek nilai emas dimasa yang akan datang bagi para investor merupakan suatu yang cukup penting.(Azzahra et al., 2018)

Logam Mulia atau emas mempunyai berbagai aspek yang menyentuh kebutuhan manusia di samping memiliki nilai estetis yang tinggi juga merupakan jenis investasi yang nilainya stabil, likuid, dan aman secara real, dan yang keempat, produk Amanah yakni produk kepemilikan kendaraan bermotor juga untuk jumlah pembiayaan tertentu bisa dengan emas.(Rahmawati, 2018)

Emas biasa dijadikan investasi jangka panjang, karena keuntungan investasi emas mudah diuangkan, tidak ada pajak dan investasi emas karena memiliki sifat yang tahan terhadap inflasi. Sifat ketahanan itu yang membuat tertarik investor untuk berinvestasi.(Wati, 2019)

Investasi merupakan suatu kegiatan penanaman modal dapat satu atau lebih aktiva yang dilakukan oleh individu maupun institusional, dengan harapan mendapatkan keuntungan (return) di masa mendatang. (Aprilia et al., 2016)

Prediksi adalah memperkecil kesalahan, sehingga selisih antara perkiraan dengan kejadian yang sebenarnya diminimalkan. Suatu prediksi tidak dapat dipastikan tepat sepenuhnya, tetapi memungkinkan untuk memberikan hasil yang mendekati dengan kejadian sebenarnya(Halimi et al., 2019)

Data Mining adalah serangkaian proses untuk menggali nilai tambah berupa informasi yang selama ini tidak di ketahui secara manual dari suatu basis data. Informasi yang di hasilkan di peroleh dengan cara mengekstrasi dan mengenali pola yang penting atau menarik dari data yang terdapat basis data(Wulandari, 2017)

secara umum data mining terbagi atas 2 (dua) kata yaitu:

1. Data Yaitu Kumpulan fakta yang terekam atau sebuah entitas yang tidak memiliki arti dan selama ini terabaikan

2. Mining yaitu proses penambangan

Sehingga data mining itu dapat di artikan sebagai proses penambangan data yang menghasilkan output (keluaran) berupa pengetahuan(Widi Norfiansyah ,Gunawan \& Dicky, 2015)

Data mining membahas penggalian atau pengumpulan informasi yang berguna dari kumpulan data. Informasi yang biasanya dikumpulkan adalah pola-pola tersembunyi pada data, hubungan antar elemen-elemen data, ataupun pembuatan model untuk keperluan peramalan data(Adinugroho \& Sari, 2018)

\section{METODE PENELITIAN}

\section{A. Tahapan Penelitian}

Metode penelitian pada dasarnya merupakan cara ilmiah untuk mendapatkan data dengan tujuan dan kegunaan tertentu(Sugiyono, 2019). Metodologi Penelitian merupakan tahap-tahap penelitian yang sistematis untukmembantu penelitian menjadi terarah dengan baik. Berikut adalah metodologi penelitian yang dilakukan penulis. 


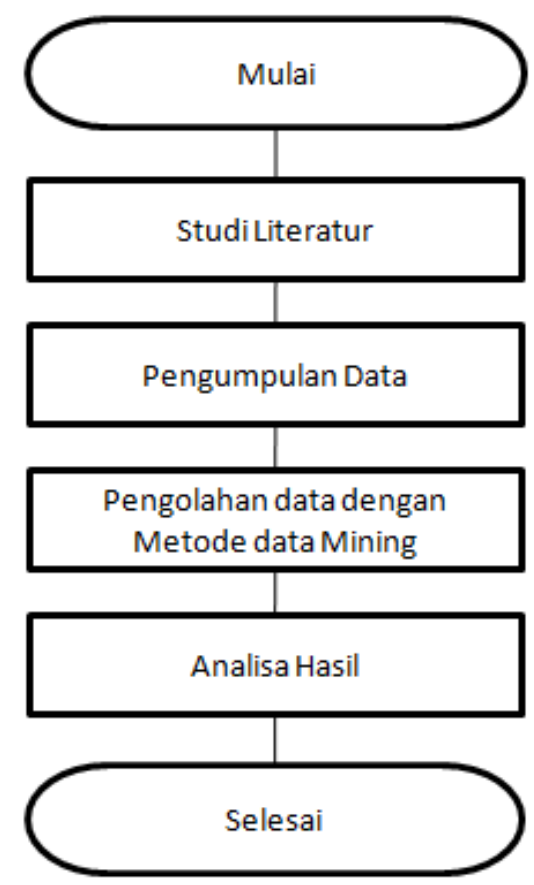

Gambar 1 Tahapan Penelitian

B. Metode Pengumpulan Data

Penulis melakukan wawancara dan observasi untuk mengetahui informasi yang dibutuhkan penulis melakukan pengumpulan data kurs rupiah di situs dan harga emas di situs badan pusat statistik pada bulan Januari 2016 sampai Desember 2019. Data yang didapatkan dari badan pusat stasistik diolah dengan cara mengklasifikasikan data data tersebut kedalam kategori Naik dan tidak. Selanjutnya melakukan pengolahan data dengan membentuk data training dan data testing, di analisa menggunakan metode klasifikasi naive bayes untuk menentukan Profit Ya dan tidak. Penulis melakukan analisis dari hasil pengolahan data dengan menggunakan aplikasi data mining yaitu rapidminer. Aplikasi tersebut digunakan untuk menganalisa dan mengukur atau menentukan Profit dalam investasi emas. Kemudian mengukur tingkat akurasi dari hasil pengolahan data tersebut untuk menentukan Profit dalam 1 Tahun kedapan

\section{Populasi}

Populasi merupakan obyek dan benda-benda alam yang berada disekitar. Populasi juga bukan hanya sekedar jumlah yang ada pada obyek maupun subyek yang dipelajari.(Sugiyono, 2019) Populasi yang digunakan berupa harga kurs rupiah pada dan harga emas pada situs Badan pusat statistik selama 3 tahun dari bulan Januari 2016 sampai bulan Desember 2019

\section{Sample Penelitian}

Dalam melakukan penelitian terhadap populasi yang baik dan benar, peneliti menggunakan teknik pengambilan sampel(Sugiyono, 2019). Teknik sampling yang penulis gunakan yaitu simple random sampling transaksi Harga Kurs Rupiah dan Harga emas selama 3 tahun berdasar situs BPS.

Tabel I.1

Daftar Transaksi Kurs Rupiah

\begin{tabular}{|c|c|c|}
\hline No & Periode & Kurs Rupiah \\
\hline 1 & 2016 Januari I & 13874 \\
\hline 2 & 2016 Januari II & 13850 \\
\hline 3 & 2016 Januari III & 13893 \\
\hline 4 & 2016 Januari IV & 13870 \\
\hline 5 & 2016 Febuari I & 13755 \\
\hline 145 & 2019 Desember IV & 13978 \\
\hline \multicolumn{3}{|c|}{ Sumber: Badan Pusat Stastitik Indonesia (2020) }
\end{tabular}


Tabel I.2

Daftar Transaksi Harga jual beli emas

\begin{tabular}{|c|c|c|}
\hline No & Periode & Harga Emas \\
\hline 1 & 2016 Januari I & 474000 \\
\hline 2 & 2016 Januari II & 474000 \\
\hline 3 & 2016 Januari III & 484000 \\
\hline 4 & 2016 Januari IV & 484000 \\
\hline 5 & 2016 Febuari I & 390000 \\
\hline 145 & 2019 Desember IV & 636072 \\
\hline
\end{tabular}

Sumber : Badan Pusat Statistik indonesia (2020)

\section{E. Naïve Bayes}

Menurut (Adinugroho \& Sari, 2018) Naive Bayes Clasifier Mengunakan dasar Toerema Bayes untuk memperkirakan kejadian bersyarat munculnya suatu kelas dengan asumsi bahwa variabel - variabel yang mempengaruhinya bersifat independen.

Menurut (Wulandari, 2017) Teori keputusan bayes adalah pendekatan statiska yang fudenmental dalam data mining. Pendekatan ini di dasarkan pada kuantifikasi trade-off antara berbagai keputusan klasifikasi dengan mengunkan probalitas

Menurut (Suyanto, 2019) Metode analisa data menggunakan Naive Bayes Classifier (NBC) yang merupakan sebuah pengaplikasian probabilitas sederhana yang mengaplikasikan teorema bayes dengan asumsi ketidak tergantungan yang tinggi. Keuntungan algoritma Naive Bayes adalah hanya membutuhkan jumlah data pelatihan (data training) berdasarkan histori data untuk menentukan estimasi parameter yang diperlukan dalam proses pengaplikasian. Dengan cara melihat peluang yang sering terjadi lalu di hitung kemungkinan munculnya seperti berapa muncul angka enam pada dadu. Dapat kita lihat peluangnya adalah 1/6 karena dadu mempunyai 6 sisi yaitu sisi angka satu sampai angka enam. Dan kita bisa memprediksi angka enam dalam permainan berikutnya amgka eman yang akan muncul atau tidak. $P(H \mid X)=\frac{\mathrm{P}(\mathrm{X} \mid \mathrm{H}) \mathrm{P}(\mathrm{X})}{\mathrm{P}(\mathrm{X})}$

Dimana $\mathrm{X}$ adalah bukti, $\mathrm{H}$ adalah hipotesis, $\mathrm{P}(\mathrm{H} \mid \mathrm{X})$ adalah probabilitas bahwa hipotesis $\mathrm{H}$ benar untuk bukti $\mathrm{X}$ atau dengan kata lain syarat $\mathrm{X}, \mathrm{P}(\mathrm{H} \mid \mathrm{X})$ merupakan probabilitas posterior $\mathrm{H}$ dengan syarat $\mathrm{X}, \mathrm{P}(\mathrm{X} \mid \mathrm{H})$ adalah probabilitas bahwa bukti $\mathrm{X}$ benar untuk hipotesis $\mathrm{H}$ atau probabilitas posterior $\mathrm{X}$ dengan syarat $\mathrm{H}, \mathrm{P}(\mathrm{H})$ adalah probabilitas prior hipotesis $\mathrm{H}$, dan $\mathrm{P}(\mathrm{X}) \mathrm{X}$ adalah probabilitas prior bukti $\mathrm{X}$.

\section{F. Penelitian Terkait}

Penelitian M. Syukri Mustafa melakukan Evaluasi Kinerja Akademik Mahasiswa menggunakan teknik data mining algoritma Naive Bayes Classifier (NBC) untuk membentuk tabel probabilitas sebagai dasar proses klasifikasi kinerja akademik mahasiswa yang kelulusannya akan diklasifikasikan dan memberikan rekomendasi untuk proses kelulusan tepat waktu yang paling tepat dengan nilai optimal berdasarkan histori nilai yang telah ditempuh mahasiswa. Sampel nilai yang digunakan untuk data latih dan testing adalah nilai mahasiswa angkatan 2008-2011 yang sudah dinyatakan lulus, sedangkan mahasiswa angkatan 2013-2014 dan belum lulus akan digunakan sebagai data target. Hasil yang diperoleh dari penelitian ini menunjukkan bahwa faktor yang paling mempengaruhi penentuan klasifikasi kinerja akademik seorang mahasiswa adalah Indeks Prestasi (IP) pada semester 1,2,3,4 dan jenis kelamin, sehingga faktor tersebut dapat menjadi bahan evaluasi terhadap pihak pengelola STMIK Dipanegara.(Mustafa et al., 2018)

Penelitian Guntur dkk. tentang Prediksi Harga Emas dengan Menggunakan Metode Naïve Bayes dalam Investasi untuk Meminimalisasi Resiko.mengunakan mengunakan Naïve Bayes Classifier.mengambilData emas yang diolah bersumber dari hasil observasi di website www.pegadaian.co.id dari tanggal 1 Desember $2017-1$ Januari 2018. Data emas diolah menggunakan software Rapidminer. dari hasil perhitungan yang telah dilakukan, metode Naïve Bayes Classifier mampu digunakan untuk memprediksi harga emas untuk 14 hari kedepan, data yang digunakan untuk pengujian sebanyak 16 data dan diperoleh tingkat akurasi sebesar 75\%, dengan hasil ini diharapkan dapat membantu para investor untuk mengambil keputusan dengan baik.(Guntur, Mohammad; Santony, 2018)

Emerensye S. Y. Pandie melakukan Penelitian Penerapan Implementasi algoritma data mining naive bayes pada koperasi.Naive Bayes merupakan teknik prediksi berbasis probabilistik sederhana berbasis pada penerapan aturan bayes.menghasilkan tingkat kebenaran sebesar $94 \%$. (Pandie et al., 2018)

Gustientiedina Dkk. melakukan Penelitian menggunakan metode Naïve Bayes untuk mengukur kualitas pelayanan akademis pada beberapa perguruan tinggi di Pekanbaru. Target khusus yang ingin dicapai adalah untuk memperoleh informasi penting secara kuantitatif dalam pengukuran kualitas pelayanan akademis di 
perguruan tinggi sebagai bahan pertimbangan dalam pengambilan keputusan dan mengembangkan sistem yang dapat membantu masyarakat perguruan tinggi dalam menggambil kebijakan yang berhubungan dengan peningkatan kualitas pelayanan akademis. Naïve Bayes merupakan teknik prediksi berbasis probabilistik sederhana yang berdasar pada penerapan teorema atau aturan bayes dengan asumsi independensi yang kuat pada fitur. Indikator penilaian yang digunakan adalah tangible (bukti langsung), reability (keandalan), responsiveness (daya tanggap), assurance (jaminan), dan empathy (empati). Penerapan Naïve Bayes ini diharapkan mampu untuk memprediksi tingkat kepuasan mahasiswa terhadap kualitas pelayanan akademis pada perguruan tinggi.(Gustientiedina et al., 2019)

\section{HASIL DAN PEMBAHASAN}

\section{Prediksi}

Algoritma Prediksi Biasanya di gunakan untuk Memperkirakan atau forcasting suatu kejadian tertentu terjadi.(Widi Norfiansyah ,Gunawan \& Dicky, 2015).Berikut tahapan prediksi yang di lakukan oleh penulis.

1. Mempelajari data yang telah ada sebelumnya

2. Mempelajari kemungkinan yang akan terjadi berdasarkan data data sebelumnya

3. Menentukan faktor yang mengengaruhi perubahan nilai

4. Melakukan pengujian data yang di prediksi dengan data aktual

\section{Instrumen Penelitian}

Perangkat Lunak Dalam melakukan penelitian, peneliti menggunakan beberapa perangkat lunak berikut :

a. Sistem operasi yang digunakan adalah Microsoft Windows 10 Pro.

b. Microsoft Office Excel untuk perhitungan manual data Processing data.

c. Rapid Miner sebagai tools pembantu menganalisa data dalam menguji aturan Naïve bayes.

1. Data Training

Data training merupakan data yang telah di olah berdasarkan data kurs Rupiah dengan Harga Emas berdasarkan Periode januari 2016 sampai desember 2019 .

\begin{tabular}{|c|c|c|c|c|c|c|}
\hline No & Periode & Kurs Rupiah & Kurs Naik & Harga Emas & $\begin{array}{c}\text { Harga } \\
\text { Naik }\end{array}$ & Profit \\
\hline 1 & 2016 Januari I & 13874 & Naik & 474000 & Turun & Tidak \\
\hline 2 & 2016 Januari II & 13850 & Turun & 474000 & Tetap & Tidak \\
\hline 3 & 2016 Januari III & 13893 & Naik & 484000 & Naik & Ya \\
\hline 4 & 2016 Januari IV & 13870 & Turun & 484000 & Tetap & Tidak \\
\hline 5 & 2016 Febuari I & 13755 & Turun & 390000 & Turun & Tidak \\
\hline 145 & 2019 Desember IV & 13978 & Turun & 636072 & Naik & Ya \\
\hline
\end{tabular}

2. Data Testing

Data testing merupakan data yang akan di uji berdasarkan asumsi prediksi tahun 2021.

\begin{tabular}{|r|c|c|c|c|c|c|}
\hline No & Periode & Kurs Rupiah & Kurs Naik & Harga Emas & $\begin{array}{c}\text { Harga } \\
\text { Naik }\end{array}$ & Profit \\
\hline 1 & 2021 Januari I & 14903 & Turun & 984.000 & Naik & Ya \\
\hline 2 & 2021 Januari II & 14812 & Turun & 990.000 & Turun & Ya \\
\hline 3 & 2021 Januari III & 14871 & Naik & 990.000 & Tetap & Ya \\
\hline 4 & 2021 Januari IV & 14875 & Naik & 1.003 .000 & Naik & Ya \\
\hline 5 & 2021 Febuari I & 14810 & Turun & 1.009 .905 & Naik & Ya \\
\hline 52 & 2021 Desember V & 16325 & Naik & 1.020 .000 & Naik & Ya \\
\hline
\end{tabular}

\section{Kriteria Penelitian}

Tahap awal cara kerja dari proses perhitungan Naive Bayes adalah dengan melakukan pengambilan data training dari data Kurs Rupiah dan Harga emas . Adapun variabel penetu yang digunakan dalam mengklarifikasi data Kurs Rupiah dan Harga emas yaitu:

a. Kurs rupiah 
Merupakan variable yang di kelompokan dalam dua kategori yaitu:

$<=13660$ dan $>=13661$ dari data kurs rupiah

b. Kurs naik

Merupakan variable yang di kelompokan dalam tiga kategori yaitu:

Naik ,Tetap dan Turun

c. Harga emas

Merupakan variable yang di kelompokan dalam dua kategori yaitu:

$<=400000$ dan $>=400001$ dari data harga emas

d. Harga Naik

Merupakan variable yang di kelompokan dalam tiga kategori yaitu:

Naik ,Tetap dan Turun

\section{Pelatihan dan Pengujian}

Langkah Pertama yang di lakukan adalah melakukan pelatihan terhadap data training yang telah di buat

A. Hasil Perhitungan Probalitas tiap kelas

Berikut ini adalah hasil perhitungan probalitas di mana terdapat dua kelas yaitu ya dan tidak.

Tabel II.1

Probalitas Prior pada tiap kelas

\begin{tabular}{|c|c|c|c|c|}
\hline No. & Kelas & Jumlah & Total Data & Probabilitas \\
\hline 1 & Ya & 68 & 145 & 0,4689655 \\
\hline 2 & Tidak & 77 & 145 & 0,5310345 \\
\hline
\end{tabular}

Pada table di atas kemungkinan profit yang di dapat :

Profit Ya 68/145 | Profit Tidak 77/145

Profit Ya $=0,4689655 \mid$ Profit Tidak $=0,5310345$.

B. Hasil Perhitungan Probalitas tiap Atribut per kelas

Terdapat 4 Kritertia / atribut yang di gunakan dalam penelitian ini berikut ini hasil perhitungan perhitungan probalitas Masing - masing berikut :

1. Kurs Rupiah

Tabel II.2

Probalitas Artibut Kurs Rupiah

\begin{tabular}{|c|c|c|c|c|c|c|c|}
\hline \multirow{2}{*}{ No. } & \multirow{2}{*}{$\begin{array}{c}\text { Kurs } \\
\text { Rupiah }\end{array}$} & \multicolumn{3}{|c|}{ Ya } & \multicolumn{3}{c|}{ Tidak } \\
\cline { 3 - 8 } & Jumlah & $\begin{array}{c}\text { Kelas } \\
\text { Ya }\end{array}$ & Probabilitas & Jumlah & $\begin{array}{c}\text { Kelas } \\
\text { Tidak }\end{array}$ & Probabilitas \\
\hline 1 & $<=13660$ & 34 & 68 & 0,5 & 50 & 77 & 0,64935065 \\
\hline 2 & $>=13661$ & 34 & 68 & 0,5 & 27 & 77 & 0,35064935 \\
\hline
\end{tabular}

Pada table di atas kita bisa melihat kemungkinan peluang dari kriteria kurs rupiah :

Kelas $<=13660$ Profit Ya 34/68 | Profit Tidak 50/77

Profit Ya $=0,5 \mid$ Profit Tidak $=0,64935065$

Kelas >=13661 Profit Ya 34/68 | Profit Tidak 20/77

Profit Ya yaitu 0,5 | Profit Tidak yaitu 0,35064935

Penentuan Kelas kurs rupiah di ambil berdasarkan nilai rata - rata kurs rupiah pada data training

2. Kurs Naik

Tabel II.3

Probalitas Artibut Kurs Naik

\begin{tabular}{|c|c|c|c|c|c|c|c|}
\hline \multirow{2}{*}{ No. } & \multirow{2}{*}{ Kurs Naik } & \multicolumn{3}{|c|}{ Ya } & \multicolumn{3}{c|}{ Tidak } \\
\cline { 3 - 8 } & Jumlah & $\begin{array}{c}\text { Kelas } \\
\text { Ya }\end{array}$ & Probabilitas & Jumlah & $\begin{array}{c}\text { Kelas } \\
\text { Tidak }\end{array}$ & Probabilitas \\
\hline 1 & Naik & 35 & 68 & 0,51470588 & 45 & 77 & 0,58441558 \\
\hline 2 & Tetap & 0 & 68 & 0 & 1 & 77 & 0,01298701 \\
\hline
\end{tabular}




\begin{tabular}{|l|l|l|l|l|l|l|l|}
3 & Turun & 33 & 68 & 0,48529412 & 31 & 77 & 0,4025974 \\
\hline
\end{tabular}

Pada table di atas kita bisa melihat melihat kemungkinan peluang dari kriteria kurs naik :

Kelas Naik Profit Ya 35/68 | Profit Tidak 45/77

Profit Ya $=0,51470588 \mid$ Profit Tidak $=0,58441558$

Kelas Tetap Profit Ya 0/68 | Profit Tidak 1/77

Profit Ya $=0 \mid$ Profit Tidak $=0,01298701$

Kelas Turun Profit Ya 33/68 | Profit Tidak 31/77

Profit Ya= 0,48529412 | Profit Tidak $=0,4025974$

3. Harga Emas

Tabel II.4

Probalitas Artibut Harga Emas

\begin{tabular}{|l|l|l|l|l|l|l|l|}
\hline \multirow{2}{*}{ No. } & \multirow{2}{*}{ Harga Emas } & \multicolumn{3}{|c|}{ Ya } & \multicolumn{3}{c|}{ Tidak } \\
\cline { 3 - 9 } & Jumlah & $\begin{array}{l}\text { Kelas } \\
\text { Ya }\end{array}$ & Probabilitas & Jumlah & $\begin{array}{l}\text { Kelas } \\
\text { Tidak }\end{array}$ & Probabilitas \\
\hline 1 & $<=400000$ & 1 & 68 & 0,01470588 & 77 & 77 & 1 \\
\hline 2 & $>=400001$ & 67 & 68 & 0,98529412 & 0 & 77 & 0 \\
\hline
\end{tabular}

Pada table di atas kita bisa melihat kemungkinan peluang dari kriteria kurs rupiah :

Kelas $<=400000$ Profit Ya 1/68 | Profit Tidak 77/77

Profit Ya $=0,01470588 \mid$ Profit Tidak $=1$

Kelas >=400001 Profit Ya 67/68 | Profit Tidak 0/77

Profit Ya yaitu 0,98529412| Profit Tidak yaitu 0

Penentuan Kelas kurs rupiah di ambil berdasarkan nilai rata - rata harga emas pada data training

4. Harga Naik

Tabel II.5

Probalitas Artibut Harga Naik

\begin{tabular}{|l|l|l|l|l|l|l|l|}
\hline \multirow{2}{*}{ No. } & \multirow{2}{*}{$\begin{array}{l}\text { Harga } \\
\text { Naik }\end{array}$} & \multicolumn{4}{|c|}{ Ya } & \multicolumn{3}{c|}{ Tidak } \\
\cline { 3 - 8 } & Jumlah & $\begin{array}{l}\text { Kelas } \\
\text { Ya }\end{array}$ & Probabilitas & Jumlah & $\begin{array}{l}\text { Kelas } \\
\text { Tidak }\end{array}$ & Probabilitas \\
\hline 1 & Naik & 68 & 68 & 1 & 1 & 77 & 0,01298701 \\
\hline 2 & Tetap & 0 & 68 & 0 & 23 & 77 & 0,2987013 \\
\hline 3 & Turun & 0 & 68 & 0 & 53 & 77 & 0,68831169 \\
\hline
\end{tabular}

Pada table di atas kita bisa melihat kemungkinan peluang dari kriteria kurs naik :

Kelas Naik Profit Ya 68/68 | Profit Tidak 1/77

Profit Ya $=1 \mid$ Profit Tidak $=0,01298701$

Kelas Tetap Profit Ya 0/68 | Profit Tidak 23/77

Profit Ya yaitu 0| Profit Tidak yaitu 0,2987013

Kelas Turun Profit Ya 0/68 | Profit Tidak 53/77

Profit Ya yaitu 0| Profit Tidak yaitu 0,68831169

Berdasarkan seluruh artribut di atas maka yang mempunyai pengaruh terbesar adalah harga naik sedangkan yang mempunyai pengaruh yang terkecil adalah kurs rupiah dalam menentukan harga emas naik ya atau tidak.

C. Pengujian terhadap Data testing

Langkah Berikutnya yang di lakukan adalah melakukan pengujian terhadap data testing mengunakan aplikasi rapid miner yang di prediksi oleh penulis pada tahun 2021

D. Hasil perhitungan akurasi

Hasil perhitungan aplikasi menggunakan data testing dan di bandingkan dengan data training maka di peroleh tingkat akurasi berikut: 
Tabel II.6

Hasil Perituangan Aplikasi Fold Cross Validation

\begin{tabular}{|l|l|l|}
\hline $\mathrm{N}=49$ & Aktual Ya & Aktual Tidak \\
\hline Prediksi Ya & $\mathrm{TP}=23$ & $\mathrm{FP}=0$ \\
\hline Perdiksi Tidak & $\mathrm{FN}=2$ & $\mathrm{TN}=24$ \\
\hline
\end{tabular}

\begin{tabular}{|c|c|c|c|}
\hline No. & Nama Pengukuran & Rumus & Hasil \\
\hline 1 & Accuracy & $\frac{(\mathrm{TP}+\mathrm{TN})}{\mathrm{N}}$ & $95,92 \%$ \\
\hline
\end{tabular}

Berdasarkan Tabel di atas maka akurasi dari data training dan data testing adalah $95.92 \%$

E. Implementasi Dalam Rapid Miner

Data Training yang telah di olah lalu di uji oleh data testing menggunakan rapid miner peroleh tingkat akurasi berikut:

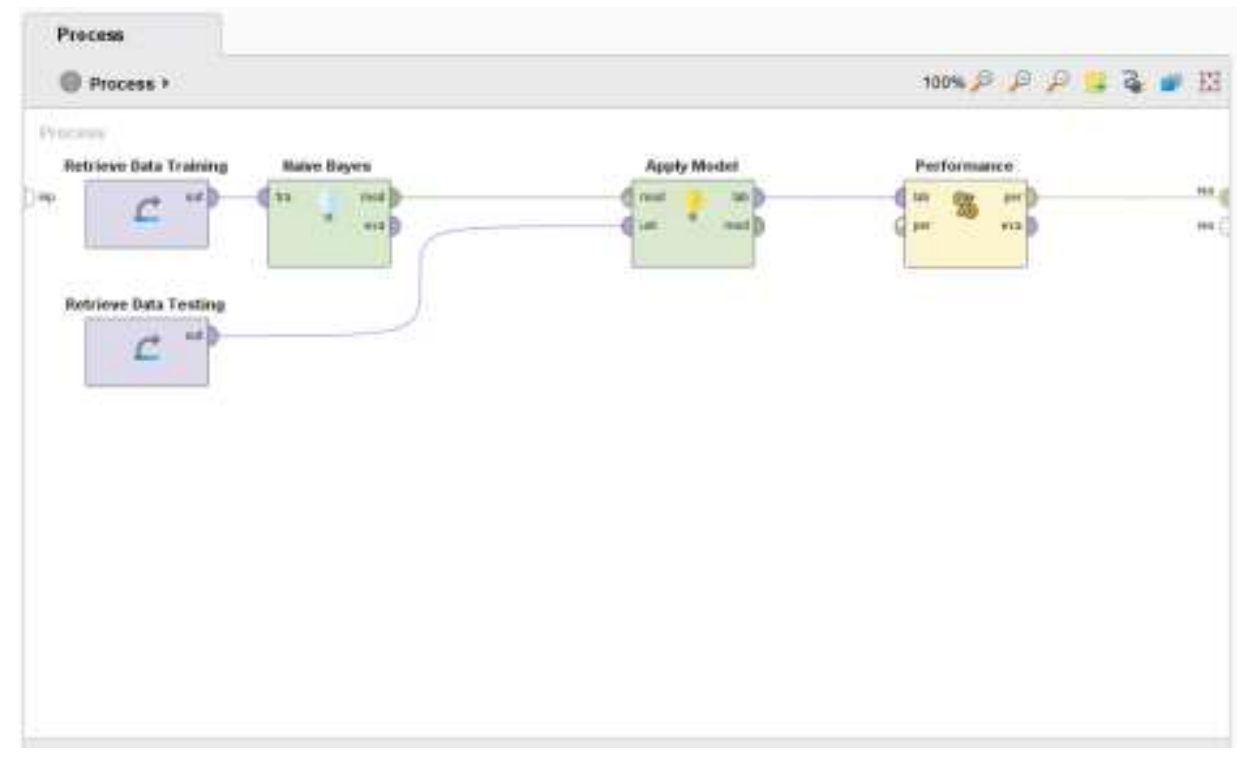

Gambar II

Proses Implementasi Fold Cross Validation

\begin{tabular}{|l|l|l|l|}
\hline \multicolumn{2}{|c|}{ accuracy: $95.92 \%$} & true Tidak & class precision \\
\hline pred. Ya & 23 & 0 & $100.00 \%$ \\
\hline pred. Tidak & 2 & 24 & $92.31 \%$ \\
\hline class recall & $92.00 \%$ & $100.00 \%$ & \\
\hline
\end{tabular}

Gambar III

Hasil Proses Implementasi Fold Cross Validation

Pada gambar di atas akurasi metode naïve bayes dengan menguji data training dan data testing di dapat akurasi $95,92 \%$ dimana sudah cukup baik. Data yang di prediksi ya sama dengan aktualnya ada 25 kemudian data yang di prediksi ya tetapi aktualnya tidak ada 0 sedangkan Data yang di prediksi tidak tetapi aktualnya ya ada 2 dan data Data yang di prediksi tidak dan aktualnya tidak ada 24. Berdasarkan seluruh data pada tabel prior artirbut harga naik mempunyai pengaruh yang berpengaruh terhadap profit. 


\section{F. Kelebihan dan kekurangan data harian}

Data harian adalah data yang dilakukan setiap hari yang di simpan kedalam sistem.yang menjadi kelebihkan data harian yaitu:

3. Data yang di simpan lengkap dan rinci

4. Data yang di lihat sangat detail dalam pencarian data

5. Melihat data sesuai yang di perlukan

Adapun juga kelemahan data harian:

1. Data yang di tampung menjadi sangat banyak

2. Penggunaan penyimpanan menjadi sangat besar

3. Proses pencarian data menjadi cukup lama.

\section{G. Kelebihan dan kekurangan data mingguan}

Data mingguan adalah laporan dari data harian yang dilakukan setiap satu minggu yang di simpan kedalam sistem.yang menjadi kelebihkan data mingguan yaitu:

1. Mempermudah informasi yang di dapat dalam pencarian

2. Data yang di lihat sangat lengkap dalam 1 minggu

3. Mempercepat pencarian data dalam skala per minggu

4. Penyimpan lebih efisien

Adapun juga kelemahan data harian:

1. Ada informasi yang kurang lengkap

2. Mencari data sedikit sulit di lakukan jika hanya mencari 1 hari

3. Data yang digunakan lebih banyak

\section{KESIMPULAN}

Berdasarkan penelitian yang telah di lakukan pada Kurs rupiah dan Harga emas mengenai Prediksi Harga Emas Menggunakan Metode Naive Bayes maka dari hasil penelitian dapat di tarik kesimpulan sebagai berikut:

1. Prediksi harga emas dapat dilakukan dengan Menganalisa data kurs rupiah serta harga emas di masa lalu menggunakan Algoritma Naïve Bayes

2. Algoritma Naïve Bayes dapat di gunakan untuk memprediksi profit investasi emas dengan akurasi yang cukup baik Yaitu 95,92\%

3. Bahwa faktor yang paling mempengaruhi kenaikan harga emas dalam profit investasi emaskenaikan harga emas Perubahan kurs Rupiah.

\section{REFERENSI}

Adinugroho, S., \& Sari, Y. A. (2018). Implementasi Data Mining Menggunakan Weka. UB Press.

Aprilia, A., Handayani, S., \& Hidayat, R. (2016). Analisis Keputusan Investasi Berdasarkan Penilaian Harga Saham (Studi Menggunakan Analisis Fundamental dengan Pendekatan Price Earing Ratio (PER) Pada Saham Sektor Pertambangan yang Listing di BEI Periode 2012-2014). Jurnal Administrasi Bisnis S1 Universitas Brawijaya, 32(1), 58-65.

Azzahra, M., Darma Setiawan, B., \& Pandu Adikara, P. (2018). Optimasi Parameter Support Vector Regression Dengan Algoritme Genetika Untuk Prediksi Harga Emas. Jurnal Pengembangan Teknologi Informasi Dan Ilmu Komputer, 2(1), 2548-2964. http://j-ptiik.ub.ac.id

Guntur, Mohammad;Santony, J. (2018). Prediksi Harga Emas dengan Menggunakan Metode Naïve Bayes dalam. (Rekayasa Sistem Dan Teknologi Informasi), 2(1), 354-360.

Gustientiedina, G., Siddik, M., \& Desnelita, Y. (2019). Penerapan Naïve Bayes untuk Memprediksi Tingkat Kepuasan Mahasiswa Terhadap Pelayanan Akademis. Jurnal Infomedia, 2(4), 2-6. https://doi.org/http://dx.doi.org/10.30811/jim.v4i2.1892

Halimi, I., Azhar, Y., \& Indah Marthasari, G. (2019). Prediksi Harga Emas Menggunakan Univariate Convolutional Neural Network. Infomatek, 21(2). https://doi.org/10.23969/infomatek.v21i2

Haryanto, K. W., \& Saputra, R. A. (2018). Aplikasi Prediksi Masa Studi Mahasiswa Menggunakan Algoritma 
Naïve Bayes Classifier ( Nbc ) ( Studi Kasus : Di Stmik Yadika Bangil ). Jurnal SPIRIT Vol. 10 No. 1 Mei 2018, 10(1), 5-12.

Mustafa, M. S., Ramadhan, M. R., \& Thenata, A. P. (2018). Implementasi Data Mining untuk Evaluasi Kinerja Akademik Mahasiswa Menggunakan Algoritma Naive Bayes Classifier. Creative Information Technology Journal, 4(2), 151. https://doi.org/10.24076/citec.2017v4i2.106

Pandie, E. S. Y., Komputer, J. I., \& Cendana, U. N. (2018). Implementasi Algoritma Data Mining Naive Bayes. $6(1), 15-20$.

Rahmawati, M. F. (2018). Investasi Logam Mulia (Emas) Di Penggadaian Syariah Dalam Persfektif Hukum Ekonomi Syariah. Tahkim, XV(1), 63-74.

Riduan, M., Hariwijaya, I., Furqon, M. T., \& Dewi, C. (2020). Prediksi Harga Emas Dengan Menggunakan Metode Average-Based Fuzzy Time Series. 4(4), 1258-1264.

Sugiyono. (2019). Metode Penelitian Kuantitatif Kualitatif Dan R\&D (2nd Ed.). Alfabeta.

Suyanto. (2019). Data Mining Untuk Klasifikasi Dan Klasterisasi Data. Informatika.

Wahono, H., \& Riana, D. (2020). Prediksi Calon Pendonor Darah Potensial Dengan Algoritma Nä̈ve Bayes , K- Nearest Neighbors dan Decision Tree C4 . 5. 7(1), 7-14. https://doi.org/10.30865/jurikom.v7i1.1953

Wati, L. R. S. (2019). Implementasi Algoritme Extreme Learning Machine (ELM) Untuk Prediksi Harga Emas Bagi Investor. Jurnal Pengembangan Teknologi Informasi Dan Ilmu Komputer, 3(3), 2408-2415.

Widi Norfiansyah ,Gunawan, \& Dicky, N. (2015). Algoritma Data Mining dan Pengujian. Deepublish.

Wulandari, R. T. (2017). Data Mining Teori dan Aplikasi Rapid Miner. GAVA MEDIA. 